\title{
Influence of different water access status of suckling calves on performance, water intake behavior and some blood metabolites
}

\author{
Mohsen ZAREI ${ }^{1, a}$, Jamal SEIFDAVATI ${ }^{1, b, \bigotimes}$, Gholam Reza GHORBANI $^{2, \mathrm{c}}$, \\ Hosein ABDI-BENEMAR ${ }^{1, \mathrm{~d}}$, Reza SEYEDSHARIFI ${ }^{1, \mathrm{e}}$, Abdolhamid KARIMI ${ }^{3, \mathrm{f}}$ \\ ${ }^{1}$ University of Mohaghegh Ardabili, Faculty of Agriculture and Natural Resources, Department of Animal Sciences, Ardabil; \\ ${ }^{2}$ Isfahan University of Technology, College of Agriculture, Department of Animal Science; ${ }^{3}$ Fars Agricultural and Natural Resources \\ Research and Education Center, Shiraz, Iran. \\ aORCID: 0000-0003-3002-8031; ' ${ }^{\mathrm{a} O R C I D: ~ 0000-0001-6794-4450 ; ~ ' ~} \mathrm{ORCID}$ : 0000-0002-2136-6090; \\ dORCID: 0000-0001-5318-4585; ' ORCID: 0000-0003-4593-2058; ${ }^{\mathrm{f} O R C I D: ~ 0000-0003-4147-5734 ~}$ \\ Corresponding author: jseifdavati@uma.ac.ir \\ Received date: 14.09.2019 - Accepted date: 03.12.2019
}

\begin{abstract}
This study was conducted to determine the effects of water accessibility of pre-weaning calves during milk feeding meal on performance, water intake behavior and some blood metabolites. Forty-eight Holstein calves $(39.2 \pm 5.8 \mathrm{~kg}$ of BW) were assigned to 4 treatments, which consisted of different water accessibility: 1) Ad libitum water (AW), 2) Water not available (WNA), 3) Water available after milk feeding (WAM) and 4) Water available before milk feeding (WBM). Resulted showed different water accessibility changed water consumption of calves. The water intake of AW $(1.03 \mathrm{~kg} / \mathrm{d})$ and WBM $(1.07 \mathrm{~kg} / \mathrm{d})$ treatments were higher than others. Starter intake of WBM decreased $(\mathrm{P}<0.05)$ as compared with others. Calves of WBM had higher $(\mathrm{P}<0.05)$ activity of serum AST. Blood $\mathrm{Cl}$ and $\mathrm{K}$ did not show the difference $(\mathrm{P}<0.05)$ among treatments. Serum TAC levels were higher $(\mathrm{P}<0.05)$ in WNA and WAM calves. Serum protein and HDL in WNA calves were higher $(\mathrm{P}<0.05)$ than others. These groups had higher $(\mathrm{P}<0.05)$ serum Na concentration than others. The different water accessibility of calves had no significant effects on health score, respiratory, fecal score and growth parameters. Treatments did not affect behaviors parameters. But the number of visiting water bucket of AW and WBM were higher than other groups. Acetic acid and propionic acid of AW calves significantly increased $(\mathrm{P}<0.05)$ as versus other treatments. Drinking water around milk feeding meal change water consumption, performance and improve some blood metabolites and rumen parameters of calves but did not influence growth parameters.
\end{abstract}

Keywords: Blood metabolites, calves, growth factor, performance, water intake.

\section{Introduction}

Water is an important nutrient in dairy production (26). According to previous research, 69.5 to $71.6 \%$ of the calf body weight is made up of water (6). Too often, it is assumed that if a calf is being fed a liquid diet, its needs for water will be satisfied (27). According to the German enactment of animal welfare and farming of animals (33) calves over 2 weeks of age have to be allowed ad libitum access to water. Feeding calves ad libitum milk during the pre-weaning period is one method to provide more water to the calves at an early stage (17). However, feeding greater amounts of milk have been shown to decrease post-weaning calf growth and decrease starter intake (3). However, milk is the primary source of water during the first few weeks of the calf's life, but represented a decreasing percentage of the total water intake as the calf became older (27). Neonate calves could consume a considerable amount of water via whole milk or milk replacer but it's not clear that amount alone would fulfill the water requirements to support growth and development (35). The drinking water requirement of calves appears to be insignificant when separated from liquid feed intake (35). Milk-fed calves drink little water until weaning, at which time water intake increases markedly (15), and water intake tends to follow the intake of solid food (19). Calves offered supplemental water gained more body weight and consumed more calf starter compared to calves without access to free water (19). Water intake of Holstein bull calves through 56 days of age was measured in 6 different trials over two years (29). In these studies, water intake was very closely correlated with starter intake. As calves consumed more starter diet they drank more water. The study, covering 30 years (27) found a significant correlation of both live-weight gain and calf starter intake with water intake prior to weaning at 5 weeks. In addition, greater water consumption has 
been shown to increase early starter intake (5). Studies have shown that consumption of solid feed in starter diets can contribute to optimized development of the rumen in calves, thereby leading to greater potential for early weaning (5). During the pre-weaning period, when calves consume whole milk or milk replacer it bypasses the rumen and goes to the abomasum via the oesophageal groove. This process also prevents a large portion of consumed water from entering the rumen and may influence bacterial growth and the start of rumen fermentation. Therefore, providing clean fresh drinking water to calves is essential for the rumen microbiota development (7). Wickramasinghe (35) reported that offering drinking water to calves from birth itself appeared to offer positive benefits even in systems promoting a large amount of liquid feed (whole milk or milk replacer) intake. Producers also seem to be hesitant to offer water to new-born calves, assuming it would cause diarrhea (4).

Overall, a lack of scientific evidence on drinking water intake of new-born calves and its effect on their performance likely encumbers the effectiveness of efforts promoting the notion of offering drinking water to newborn calves at birth. Depending on the improved starter intake and weight gain in report Kertz et al. (19), it is often hypothesized that drinking water would enhance rumen development, thus increasing nutrient availability for growth and development of calves. However, no systematic attempt has been made to study this link between water intake and nutrient availability to the animal. This also brought attention to the fact that many dairy farmers wait an hour before and after milk feeding meal to offer drinking water to suckler calves even though offering water a full day is the recommendation. Water ideally should be available at all times to young calves, but as minimum warm water should be offered after feeding and midday in cold climates (5). The hypothesis of this study is the question that "Does water drinking around milk meal affects calf health and performance?" Thus, the objectives of our experiment were to determine the effects of different water access status of suckling calves on performance, water intake behavior and some blood metabolites.

\section{Materials and Methods}

Animals, housing and diets: The research protocol was approved by the Animal Care and Use Committee of the Iranian Council of Animal Care (1995). Forty-eight Holstein calves ( $(3 \mathrm{~d}$ of age; $39.2 \pm 5.8 \mathrm{~kg}$ of body weight $(\mathrm{BW}))$ were used in this study. The experiment was carried out at Mohandesiye Dairy cattle farm, Esfahan province, Iran. This study was conducted in late 2017 and early 2018. The month average temperature was decreased monthly. The weather data of Esfahan were for the average temperatures $\left({ }^{\circ} \mathrm{C}\right)(19.2,11.2$ and 6.4), Maximum temperature $\left({ }^{\circ} \mathrm{C}\right)$ (31.6, 26.8 and 23.4), Minimum temperature $\left({ }^{\circ} \mathrm{C}\right)(6,-2.4$ and -4.8$)$ and the average wind speed $(\mathrm{m} / \mathrm{s})(1.9,1.1$ and 0.9$)$ during October, November and December months (2017), respectively.

The Mohandesiye Dairy cattle farm in Esfahan is one of the biggest farms in Esfahan that had almost 1500 cow. Total parturition days for this study to select and collect the 48 calf were about one week or 7 days. Calves were separated from their mothers within $24 \mathrm{~h}$ of birth, weighed, moved into individual pens $(1.2 \times 1.8 \mathrm{~m}$; width $x$ depth) where they were fed $10 \%$ colostrum of their BW for the first $3 \mathrm{~d}$. The pens were cleaned every $2 \mathrm{~d}$ by removing all bedding and replacing it with fresh sawdust bedding. Calves were managed according to the standard operating procedures of this research station, in accordance with guidelines set by the Iranian Council of Animal Care (16).

Calf starter was offered ad libitum, and intake was recorded daily, beginning on day 4. The basal diet was formulated to meet Nutrient Requirements of Dairy Cattle (NRC) (27) requirements for calf nutrients. The ingredients, nutrient composition of the basal diet and drinking water quality are shown in Table 1 . Chopped dried wheat straw and alfalfa hay were used after 20 days age of calves in the study. The forage was chopped using a total mixed ration mixer (Loewen Horizontal Mixer, Loewen Welding \& Manufacturing Ltd., Matsqui, BC, Canada) at 19,000 rpm for $60 \mathrm{~min}$. Three additional buckets were placed in the middle of the area where the new-born calves were housed and also weighted every 24 hours to calculate the evaporation of water. The daily water intake of a calf was calculated by the difference in weight of the buckets of each calf minus average of three bucket evaporation. All calves were fed the same amount of whole milk. Calves were bucket-fed $4.5 \mathrm{~L} / \mathrm{d}$ of whole milk divided into 3 feedings, at approximately 0800, 1630 and $0030 \mathrm{~h}$ from birth until $30 \mathrm{~d}$ of age. From d 31 to 50, calves were fed $8 \mathrm{~L} / \mathrm{d}$, using the same procedure as described above. Milk volume was reduced by $20 \%$ that means calves were fed $6.4 \mathrm{~L} / \mathrm{d}$ from d 50 to 60 , with milk weaning occurring on $\mathrm{d} 60$. Therefore, the whole experiment period was sixty days, and for fed colostrum in the first 3 days of life, the main experiment period began on the fourth day of calf birth.

On the $4^{\text {th }}$ day, the calves were randomly assigned to 4 treatments: 1) water were ad libitum (AW) 2) Inaccessibility to water an hour before and an hour after milk feeding or water not available (WNA) 3) Inaccessibility before and access to water after milk feeding milk or water available after milk feeding (WAM) and 4) Accessibility before and inaccessibility to water an hour after milk feeding or water available before milk feeding (WBM). A total of 6 water samples were collected and sent directly to a commercial laboratory for analysis (Zagros LAB water quality test, Fars, Shiraz, Z.A.F). 
Table 1. Chemical composition of diet and drinking water quality

\begin{tabular}{|c|c|c|c|}
\hline Diet composition & $\%$ of DM & Water quality & Mean \pm SEM \\
\hline Corn grain ground & 27 & Number of samples & 6 \\
\hline Barley grain ground & 35.5 & $\mathrm{EC}(\mu \mathrm{s} / \mathrm{cm})$ & $2386.00 \pm 36.97$ \\
\hline Rumen growth factor (RGF) & 14 & T.D.S $\mathrm{S}^{3}(\mathrm{mg} / \mathrm{L})$ & $1538.27 \pm 22.85$ \\
\hline Soybean meal, $45 \% \mathrm{CP}$ & 10 & $\mathrm{PH}$ & $7.27 \pm 0.11$ \\
\hline Whole soybean (full fat) & 0.8 & Nitrate $\left(\mathrm{NO}_{3}\right)(\mathrm{mg} / \mathrm{L})$ & $83.25 \pm 1.9$ \\
\hline Dicalcium phosphate & 0.8 & $\operatorname{Nitrite}\left(\mathrm{NO}_{2}\right)(\mathrm{mg} / \mathrm{L})$ & $0.014 \pm 0.004$ \\
\hline Sodium bicarbonate & 0.6 & Phosphate $\left(\mathrm{PO}_{4}{ }^{3-}\right)(\mathrm{mg} / \mathrm{L})$ & $0.03 \pm 0.07$ \\
\hline Magnesium oxide & 0.4 & Carbonate $\left(\mathrm{CO}_{3}{ }^{2-}\right)(\mathrm{meq} / \mathrm{L})$ & $0.00 \pm 0.00$ \\
\hline Salt & 0.7 & $\mathrm{HCO}^{3-}(\mathrm{meq} / \mathrm{L})$ & $5.00 \pm 0.3$ \\
\hline Vitamin permix $^{1}$ & 1.5 & $\mathrm{Cl}^{-}(\mathrm{meq} / \mathrm{L})$ & $11.50 \pm 1.05$ \\
\hline Mineral permix ${ }^{1}$ & 1.5 & $\mathrm{SO}_{4}^{2-}(\mathrm{meq} / \mathrm{L})$ & $6.00 \pm 0.8$ \\
\hline Nutrient composition & & Sum Anion & $22.50 \pm 2.4$ \\
\hline $\mathrm{ME},{ }^{2} \mathrm{Mcal} / \mathrm{kg}$ & 3.03 & $\mathrm{Ca}^{2+}(\mathrm{meq} / \mathrm{L})$ & $7.50 \pm 1.7$ \\
\hline $\mathrm{NEg},{ }^{2} \mathrm{Mcal} / \mathrm{kg}$ & 1.73 & $\mathrm{Mg}^{2+}(\mathrm{meq} / \mathrm{L})$ & $2.00 \pm 0.06$ \\
\hline DM & 90 & $\mathrm{Na}^{+}(\mathrm{meq} / \mathrm{L})$ & $15.58 \pm 1.16$ \\
\hline $\mathrm{CP}$ & 22.7 & $\mathrm{~K}^{+}(\mathrm{meq} / \mathrm{L})$ & $0.12 \pm 0.09$ \\
\hline $\mathrm{NDF}$ & 16.4 & Sum Cation & $25.20 \pm 1.84$ \\
\hline $\mathrm{ADF}$ & 8.4 & Escherichia coli $(\mathrm{cfu} / \mathrm{mL})$ & $\mathrm{ND}^{4}$ \\
\hline Lipid & 2.8 & & \\
\hline Ash & 8.0 & & \\
\hline $\mathrm{Ca}^{2}$ & 0.78 & & \\
\hline $\mathrm{P}^{2}$ & 0.55 & & \\
\hline \multicolumn{4}{|c|}{$\begin{array}{l}{ }^{1} \text { Contained per kilogram of supplement: } 250,000 \mathrm{IU} \text { of vitamin } \mathrm{A}, 50,000 \mathrm{IU} \text { of vitamin } \mathrm{D}, 1,500 \mathrm{IU} \text { of vitamin E, } 2.25 \mathrm{~g} \text { of } \mathrm{Mn} \text {, } \\
120 \mathrm{~g} \text { of } \mathrm{Ca}, 7.7 \mathrm{~g} \text { of } \mathrm{Zn}, 20 \mathrm{~g} \text { of P, } 20.5 \mathrm{~g} \text { of } \mathrm{Mg}, 186 \mathrm{~g} \text { of Na, } 1.25 \mathrm{~g} \text { of Fe, } 3 \mathrm{~g} \text { of S, } 14 \mathrm{mg} \text { of } \mathrm{Co}, 1.25 \mathrm{~g} \text { of Cu, } 56 \mathrm{mg} \text { of I, and } 10 \\
\mathrm{mg} \text { of Se. } \\
{ }^{2} \text { Calculated from NRC (27). } \\
{ }^{3} \text { Total dissolved solids based on gravimetric analysis. } \\
{ }^{4} \text { Not detected. }\end{array}$} \\
\hline
\end{tabular}

The behavioral data recording methods and their description: The ingesting water behavior was defined as the calf is ingesting water by drinking from a bucket and the ingesting grain behavior was described as the calf is consuming grain from a bucket. Also, the ruminating activities were explained as the calf is ruminating. The standing status was recorded as the calf is standing with all 4 legs on the ground. The lying in bed position was noted as the calf is resting on the ground; the head may be supported or unsupported by the neck. The object play was monitored as the calf is standing; butting head against milk or water buckets or hutch in a playful manner. The selfgrooming was observed as the calf's tongue is out of its mouth and in contact with its own body. The non-nutritive sucking was recorded the calf's tongue is out of its mouth and is in contact with or biting any fixtures of the pen; may include bucket if milk is not available at the time of observation. Other behaviors were described as the calf is urinating, defecating, or performing another behavior not described. All observations were by the same person, who was blind to treatment group's allocation to minimize possible bias in data calves. We observed calf behavior for
680 -min periods every five minutes one by one at before or after approximately 0800,1630 and $0030 \mathrm{~h}$ from after first 4 days of birth to 60 days of life into 3 calves' meals. Therefore, the visits were 80 -min before and 80 -min after milk meal in 3 times a day accordingly, means total visits were 8 hour a day that is one replicate. The observations replicated three times.

Data collection and sampling: Starter intake and orts were recorded daily on an individual basis. Feed and refusals were sampled, mixed thoroughly, and ground to pass a 1-mm screen in a Wiley mill (Ogawa Seiki Co., Ltd., Tokyo, Japan). Standard methods were used for determination of DM (dry matter), CP (crude protein), NDF (neutral detergent fiber), ADF (acid detergent fiber), fat and ash as described in AOAC (1). Calves were weighed every $10 \mathrm{~d}$ throughout the study. Structural growth measurements of body length, withers height, hip height, heart girth and hip width were recorded on basis (cm) in two periods including $\mathrm{d} 4$ and 50 of the experiment according to Lesmeister and Heinrichs (24). The four body measurements were obtained on all calves as follows: 
The body length was the distance from the point of the shoulders to the ischium; withers height was the distance from the floor beneath the calf to the top of the withers directly above the center of the shoulder; hip height of calves be standing straight on a level, hard surface with its head up, and to measure hip height, used a hip stick and place it between the hip bones at a 45 degree angle; heart girth was measured as the minimal circumference around the body immediately behind the front shoulder; hip width was the widest point at the center of the stifle. On the same day the body weights were also obtained. All linear measurements were obtained with specially designed aluminum calipers; or a plastic-coated fiber tape measure available commercially. All measurement devices were in metric graduations $(\mathrm{cm})$. Feed efficiency was calculated according to Khan et al. (20). Fecal scoring was performed every day in the morning (08.00) according to Wisconsin-Madison calf health scoring chart as follows: $0=$ Normal; $1=$ Semiformed, pasty; 2=Loose, but stays on top of the bedding; $3=$ Water, sifts through the bedding. The health criteria of the calves were observed using the procedure described in Heinrichs et al. (14) and was monitored using the procedure described in Heinrichs et al. (14). Behavior was monitored by direct observation of all the calves on 2 consecutive days (on d 35 of the experiment and before weaning once per week). Calves were observed $8 \mathrm{~h}$ around milk feeding during the pre-weaning week. Instantaneous scans were performed for occurrences of lying, standing, water and starter intake, ruminating and non-nutritive oral behaviours (28).

Ruminal fluid samples were obtained using a stomach tube $3 \mathrm{~h}$ after the morning feeding on $\mathrm{d} 35$, strained through 4-layer cheesecloth. A sample of the filtered ruminal fluid $(5 \mathrm{~mL})$ was added to $1 \mathrm{~mL}$ of metaphosphoric acid $(250 \mathrm{~g} / \mathrm{L})$ and retained for short chain fatty acids determination. Rumen samples were analyzed for VFA by gas chromatography (Model CP-9002, Chrompack, Middelburg, Netherlands) with a 50-m (0.32 $\mathrm{mm}$ internal diameter) fused-silica column (CP-Wax Chrompack Capillary Column, Varian, Palo Alto, CA).

On d 35 and 50 of the study period, jugular blood samples were also collected in evacuated tubes $(5 \mathrm{~mL}) 3 \mathrm{~h}$ after the morning feeding without adding any anticoagulant. These samples were centrifuged at $1500 \times$ $\mathrm{g}$ for $20 \mathrm{~min}$, and the serum samples obtained were stored at $-20{ }^{\circ} \mathrm{C}$ until subsequent analyses. After unfreezing, in serum samples biochemical indicators (glucose, total protein, chloride $\left(\mathrm{Cl}^{-}\right)$albumin, cholesterol, HDL, triglycerides and activity of enzymes, ALT, AST) were measured by commercial kits (Pars Azmoon, Tehran, Iran) using an automated analyser (Biotecnica, Targa 3000, Rome, Italy). Glutathione peroxidase (GPx), total antioxidant status (TAS), NEFA, BHBA and MDA was determined by Ransel ${ }^{\circledR}$ kits (Randox, UK) with UV/VIS Spectrophotometer. The amounts of sodium $(\mathrm{Na})$ and potassium $(\mathrm{K})$ were measured by a flame photometer (Jenway 6105 Clinical, Jenway LTD Felsted England).

Statistical analysis: The corrections of the collected records were on a 35-day base. All the data collected were analyzed using the MIXED procedure (Version 8, SAS Institute Inc., Cary, NC) as a completely randomized design (32). Calf within treatment was included as a random effect that was used to test the main effect of treatment. Time was modeled as a repeated measurement for starter intake, total dry matter intake (DMI), average daily gain (ADG), feed efficiency, and fecal score within d 4-50. The data on blood metabolites, rumen parameters, BW, skeletal growth and feeding behavior were analysed for two periods while those on nutrient digestibility were analysed for one period (weaning). For BW and skeletal growth, initial values were used as the covariate. The statistical model used for the analyses was $\mathrm{Y}_{\mathrm{ijklm}}=\mu+\mathrm{T}_{\mathrm{i}}+$ $\mathrm{P}_{\mathrm{j}}+\mathrm{T} \times \mathrm{P}_{\mathrm{ij}}+\mathrm{C}_{\mathrm{kij}}+1(\mathrm{Cov})_{\mathrm{m}}+\mathrm{e}_{\mathrm{ijklm}}$, where $\mathrm{Y}_{\mathrm{ijklm}}=$ observation or the dependent variable, $=$ the overall mean, $T_{i}=$ the effect of treatment $\mathrm{i}, \mathrm{P}_{\mathrm{j}}=$ the effect of period $\mathrm{j}, \mathrm{T}$ $\times \mathrm{P}_{\mathrm{ij}}=$ the effect of the interaction between treatment $\mathrm{i}$ and period $\mathrm{j}, \mathrm{C}_{\mathrm{kij}}=$ calf random effect, $\mathrm{l}=$ regression coefficient of observations on birth weight (BW) or skeletal growth as a covariate, and $\mathrm{e}_{\mathrm{ijklm}}=$ random residual effect. Values were presented as least square means. Treatment differences were declared at $\mathrm{P} \leq 0.05$, with trends towards significance considered at $\mathrm{P} \leq 0.15$.

\section{Results}

It is evident that different water accessibility around calf milk meal changed water consumption of calves (Table 2). AW and WBM significantly increased water intake of calves as compared to other treatments. Also, the water intake of calves increased with age $(\mathrm{P}<0.05)$. Results of different calves' water accessibility showed that the calves in treatments of AW and WBM had higher water intake (respectively $\mathrm{AW}=1.03 \mathrm{~kg} / \mathrm{d}$ and $\mathrm{WBM}=1.07$ $\mathrm{kg} / \mathrm{d}$ ). The mean daily water intakes of WNA and WAM treatments decreased and were $0.84 \mathrm{~kg} / \mathrm{d}$ and $0.84 \mathrm{~kg} / \mathrm{d}$, respectively. In this study, AW calves in the second decades (11 to $20 \mathrm{~d}$ ) drank $1.26 \mathrm{~kg} / \mathrm{d}$ water, that significantly higher than other groups $(\mathrm{P}<0.05)$. During decade 3, water intake of both AW $(0.95 \mathrm{~kg} / \mathrm{d})$ and WBM $(0.96 \mathrm{~kg} / \mathrm{d})$ treatments increased compared with other groups. In the 4 decades age of calves, WBM groups had more water intake $(1.10 \mathrm{~kg} / \mathrm{d})$ than other treatments. The water intake of calves in decade 5, did not differ among treatment $(\mathrm{P}>0.05)$. In the last decade, water intake of the WAM group significantly decreased compared with other treatments $(\mathrm{P}<0.05)$.

Starter intake of calves is presented in Table 2 . Starter intake affected by water accessibility treatments. 
Calves offered ad libitum water consumed an average of $39 \%$ more water than other calves in the second period $(\mathrm{P}<0.001)$. At third- and fourth-decade age calve AW and WBM treatments had higher water intake as compared with WNA and WAM treatments. Starter intake did not significantly difference between treatments.
The WBM treatments significantly reduced calves body weight rather than other treatments. Also, the ADG of WBM treatment was the lowest $(0.54 \mathrm{~kg} / \mathrm{d})$. The result showed that water accessibility of calves before milk feeding had a negative effect on performance. According to Table 2 feed efficiency of calves did not affect by treatments.

Table 2. Water intake and starter intake, performance, feed efficiency and ADG of calves $(\mathrm{n}=52)$ with different water accessibility during the preweaning period (Mean \pm SEM)

\begin{tabular}{|c|c|c|c|c|c|c|c|c|}
\hline \multirow{2}{*}{ Item } & \multicolumn{4}{|c|}{ Treatment } & \multirow{2}{*}{ SEM } & \multicolumn{3}{|c|}{$\mathbf{P}$} \\
\hline & AW & WNA & WAM & WBM & & Treat & Time & Treat xtime \\
\hline \multicolumn{9}{|c|}{ Water intake $(\mathrm{kg} / \mathrm{d})$} \\
\hline Whole period & $1.03 \pm 0.06^{\mathrm{a}}$ & $0.84 \pm 0.04^{b}$ & $0.84 \pm 0.05^{b}$ & $1.07 \pm 0.07^{\mathrm{a}}$ & 0.01 & 0.01 & 0.01 & 0.29 \\
\hline $1-10 \mathrm{~d}$ & $0.94 \pm 0.06$ & $0.86 \pm 0.06$ & $0.79 \pm 0.06$ & $0.89 \pm 0.06$ & 0.51 & 0.24 & - & - \\
\hline $11-20 \mathrm{~d}$ & $1.26 \pm 0.06^{\mathrm{a}}$ & $0.76 \pm 0.06^{\mathrm{c}}$ & $0.95 \pm 0.06^{\mathrm{bc}}$ & $0.98 \pm 0.06^{\mathrm{b}}$ & 0.06 & 0.01 & - & - \\
\hline $21-30 \mathrm{~d}$ & $0.95 \pm 0.05^{\mathrm{a}}$ & $0.69 \pm 0.05^{\mathrm{b}}$ & $0.78 \pm 0.05^{\mathrm{b}}$ & $0.96 \pm 0.05^{\mathrm{a}}$ & 0.05 & 0.01 & - & - \\
\hline $31-41 \mathrm{~d}$ & $0.92 \pm 0.06^{\mathrm{b}}$ & $0.73 \pm 0.06^{\mathrm{c}}$ & $0.76 \pm 0.06^{\mathrm{c}}$ & $1.10 \pm 0.06^{\mathrm{a}}$ & 0.05 & 0.01 & - & - \\
\hline $41-50 \mathrm{~d}$ & $1.14 \pm 0.07$ & $1.08 \pm 0.07$ & $0.94 \pm 0.07$ & $1.07 \pm 0.07$ & 0.03 & 0.21 & - & - \\
\hline $51-60 \mathrm{~d}$ & $1.28 \pm 0.09^{\mathrm{ab}}$ & $1.55 \pm 0.09^{\mathrm{a}}$ & $1.04 \pm 0.09^{\mathrm{b}}$ & $1.48 \pm 0.09^{\mathrm{a}}$ & 0.11 & 0.02 & & \\
\hline \multicolumn{9}{|c|}{ Starter intake $(\mathrm{kg} / \mathrm{d})$} \\
\hline Whole period & $0.63 \pm 0.03^{\mathrm{a}}$ & $0.62^{\mathrm{a}} \pm 0.02$ & $0.61^{\mathrm{a}} \pm 0.03$ & $0.54 \pm 0.03^{\mathrm{b}}$ & 0.02 & 0.01 & 0.01 & 0.01 \\
\hline $1-10 d$ & $0.13 \pm 0.01$ & $0.12 \pm 0.01$ & $0.12 \pm 0.01$ & $0.09 \pm 0.01$ & 0.01 & 0.17 & - & - \\
\hline $11-20 d$ & $0.29 \pm 0.02$ & $0.27 \pm 0.02$ & $0.30 \pm 0.02$ & $0.28 \pm 0.02$ & 0.01 & 0.73 & - & - \\
\hline $21-30 \mathrm{~d}$ & $0.45 \pm 0.03^{\mathrm{a}}$ & $0.44^{\mathrm{ab}} \pm 0.03$ & $0.37^{\mathrm{ab}} \pm 0.03$ & $0.36 \pm 0.03^{b}$ & 0.01 & 0.05 & - & - \\
\hline First month & $0.29 \pm 0.01$ & $0.27 \pm 0.01$ & $0.26 \pm 0.01$ & $0.24 \pm 0.01$ & 0.01 & 0.08 & 0.01 & 0.16 \\
\hline $31-41 \mathrm{~d}$ & $0.58 \pm 0.03$ & $0.63 \pm 0.03$ & $0.55 \pm 0.03$ & $0.61 \pm 0.03$ & 0.01 & 0.34 & - & - \\
\hline $41-50 \mathrm{~d}$ & $0.90 \pm 0.03$ & $0.81 \pm 0.03$ & $0.89 \pm 0.03$ & $0.84 \pm 0.03$ & 0.01 & 0.12 & - & - \\
\hline $51-60 d$ & $1.46 \pm 0.08^{\mathrm{a}}$ & $1.46^{\mathrm{a}} \pm 0.08$ & $1.43^{\mathrm{a}} \pm 0.08$ & $1.10 \pm 0.08^{b}$ & 0.04 & 0.01 & - & - \\
\hline Second month & $0.98 \pm 0.03^{\mathrm{a}}$ & $0.97^{\mathrm{a}} \pm 0.03$ & $0.96^{\mathrm{a}} \pm 0.03$ & $0.85 \pm 0.03^{b}$ & 0.01 & 0.01 & 0.01 & 0.01 \\
\hline \multicolumn{9}{|l|}{$\mathrm{BW}, \mathrm{kg}$} \\
\hline Initial, $1^{\text {th }}$ day & $39.41 \pm 1.74$ & $39.23 \pm 1.74$ & $38.92 \pm 1.74$ & $39.65 \pm 1.74$ & 0.84 & 0.99 & - & - \\
\hline Final, $56^{\text {th }}$ day & $71.69 \pm 2.80^{\mathrm{ab}}$ & $73.78 \pm 2.80^{\mathrm{a}}$ & $69.23 \pm 2.80^{\mathrm{ab}}$ & $65.29 \pm 2.80^{\mathrm{b}}$ & 2.10 & 0.03 & - & - \\
\hline $\operatorname{ADG}(\mathrm{kg} / \mathrm{d})$ & $0.70 \pm 0.04^{\mathrm{a}}$ & $0.72 \pm 0.04^{\mathrm{a}}$ & $0.62 \pm 0.04^{\mathrm{ab}}$ & $0.54 \pm 0.04^{\mathrm{b}}$ & 0.21 & 0.01 & - & - \\
\hline Feed Efficiency & $0.97 \pm 0.08$ & $0.89 \pm 0.08$ & $1.12 \pm 0.08$ & $1.07 \pm 0.08$ & 0.03 & 0.14 & & \\
\hline
\end{tabular}

Treatments: WNA=Water not available, $\mathrm{AW}=\mathrm{Ad}$ libitum water, WAM $=$ Water available after milk feeding, WBM= Water available before milk feeding.

BW: Body weight, ADG: Average daily gain

a,b Values within a row with different superscripts differ significantly at $\mathrm{P}<0.05$.

Table 3. Blood metabolite concentration for different water accessibility of Holstein calves with common starter and milk replacer $($ Mean \pm SEM)

\begin{tabular}{|c|c|c|c|c|c|c|c|c|}
\hline \multirow[t]{2}{*}{ Item } & \multicolumn{4}{|c|}{ Treatments } & \multirow[t]{2}{*}{ SEM } & \multicolumn{3}{|c|}{$\mathbf{P}$} \\
\hline & AW & WNA & WAM & WBM & & Treat & Time & Treat $\times$ time \\
\hline Glucose (mg/dL) & $128.6 \pm 6.98$ & $139 \pm 6.98$ & $130.5 \pm 6.98$ & $138 \pm 9.87$ & 3.36 & 0.68 & 0.42 & 0.72 \\
\hline Cholesterol (mg/dL) & $104.1 \pm 9.8^{\mathrm{a}}$ & $103.3 \pm 9.8^{\mathrm{a}}$ & $72.1 \pm 9.8^{\mathrm{b}}$ & $71.2 \pm 13.9^{\mathrm{b}}$ & 5.87 & 0.03 & 0.09 & 0.67 \\
\hline Triglycerides (mg/dL) & $30.8 \pm 3.05$ & $45.8 \pm 3.98$ & $53.6 \pm 34.10$ & $44.2 \pm 3.45$ & 4.03 & 0.18 & 0.08 & 0.62 \\
\hline $\operatorname{AST}(\mathrm{u} / \mathrm{L})$ & $37.5 \pm 4.37^{b}$ & $37.6 \pm 4.37^{\mathrm{b}}$ & $32.1 \pm 4.37^{\mathrm{b}}$ & $53.5 \pm 6.18^{\mathrm{a}}$ & 2.14 & 0.01 & 0.01 & 0.01 \\
\hline $\operatorname{ALT}(\mathrm{u} / \mathrm{L})$ & $7.6 \pm 0.84$ & $10.1 \pm 0.84$ & $8.1 \pm 0.84$ & $8.0 \pm 1.18$ & 0.45 & 0.15 & 0.60 & 0.37 \\
\hline TAC (mmol/L) & $0.19 \pm 0.04^{b}$ & $0.37 \pm 0.04^{\mathrm{a}}$ & $0.44 \pm 0.04^{\mathrm{a}}$ & $0.20 \pm 0.06^{\mathrm{b}}$ & 0.04 & 0.01 & 0.01 & 0.01 \\
\hline BHBA (mmol/L) & $0.10 \pm 0.02$ & $0.10 \pm 0.02$ & $0.13 \pm 0.02$ & $0.08 \pm 0.02$ & 0.01 & 0.22 & 0.47 & 0.42 \\
\hline Albumin $(\mathrm{g} / \mathrm{dL})$ & $3.53 \pm 0.09$ & $3.75 \pm 0.09$ & $3.71 \pm 0.09$ & $3.77 \pm 0.12$ & 0.04 & 0.31 & 0.67 & 0.96 \\
\hline NEFA (mmol/L) & $0.175 \pm 0.03$ & $0.185 \pm 0.03$ & $0.190 \pm 0.03$ & $0.130 \pm 0.05$ & 0.01 & 0.58 & 0.92 & 0.82 \\
\hline Protein $(\mathrm{g} / \mathrm{dL})$ & $6.51 \pm 0.14^{\mathrm{b}}$ & $7.10 \pm 0.14^{\mathrm{a}}$ & $6.86 \pm 0.14^{\mathrm{ab}}$ & $6.57 \pm 0.19^{b}$ & 0.08 & 0.01 & 0.08 & 0.14 \\
\hline $\mathrm{HDL}(\mathrm{mg} / \mathrm{dL})$ & $30.33 \pm 2.88^{a b}$ & $36.16 \pm 2.88^{\mathrm{a}}$ & $23.16 \pm 2.88^{b}$ & $23.50 \pm 4.07^{\mathrm{b}}$ & 1.82 & 0.01 & 0.09 & 0.67 \\
\hline MDA (nmol/mL) & $0.91 \pm 0.89$ & $1.05 \pm 0.09$ & $1.13 \pm 0.09$ & $0.85 \pm 0.13$ & 0.05 & 0.21 & 0.08 & 0.72 \\
\hline
\end{tabular}

Treatments: WNA=Water Not Available, AW=Adlibitum Water, WAM= Water available after milk feeding, WBM= Water available before milk feeding

a,b Values within a row with different superscripts differ significantly at $\mathrm{P}<0.05$. 
Table 3 summarizes the blood parameter data for each group and sampling date. Concentrations of glucose, cholesterol, TG, ALT, BHB, albumin, NEFA and MDA were similar among treatments (Table 3). But the serum concentrations of AST, TAC, protein and HDL significantly changed by different water accessibility. At 24-48 $\mathrm{h}$ after birth the level of total protein was in reference range but at other ages was below the reference value. In this study WBM has higher activity of serum $\operatorname{AST}(53.5 \mathrm{u} / \mathrm{L})$ as compared with other treatments.

TAC levels of serum in this study were significantly higher in group WNA and WAM than others $(\mathrm{P}<0.05)$. The treat $\times$ time interaction was statistically significant for AST and TAC. Serum concentrations of Protein and HDL in WNA treatment is significantly higher than other groups $(\mathrm{P}<0.05)$. But were not influenced by either time or treat $\times$ time.
Some blood electrolytes are presented in Table 4. The elements $\mathrm{Cl}$ and $\mathrm{K}$ did not significantly different among treatments. But Na concentration of blood serum in AW and WAM is 138.08 and 138.01, respectively. These groups had significantly higher serum concentration of $\mathrm{Na}$ than others $(\mathrm{P}<0.05)$. Water treatments did not affect the fecal score, temperature, and the respiratory score of calves, these parameters are presented in Table 5. The findings of the current study showed that different water accessibility of calves had no significant effects on health, respiratory and fecal score.

Mean body length, withers height, heart girth, body barrel, hip height and hip width during the pre-weaning periods are given in Table 6. There is no difference in frame growth and body condition scores of calves. Rumen fermentation data showed in Table 7. Acetic acid and

Table 4. Blood concentration of some electrolyte for different water accessibility of Holstein calves (Mean \pm SEM)

\begin{tabular}{|c|c|c|c|c|c|c|c|c|}
\hline \multirow[t]{2}{*}{ Item } & \multicolumn{4}{|c|}{ Treatments } & \multirow[t]{2}{*}{ SEM } & \multicolumn{3}{|c|}{$\mathbf{P}$} \\
\hline & $\mathbf{A W}$ & WNA & WAM & WBM & & Treat & Time & $\begin{array}{c}\text { Treat } \times \\
\text { time }\end{array}$ \\
\hline $\mathrm{Cl}(\mathrm{meq} / \mathrm{L})$ & $100.5 \pm 9.33$ & $93.83 \pm 9.33$ & $108.33 \pm 9.33$ & $104.75 \pm 13.20$ & 4.55 & 0.74 & 0.54 & 0.49 \\
\hline $\mathrm{Na}(\mathrm{meq} / \mathrm{L})$ & $138.08 \pm 1.16^{\mathrm{a}}$ & $137.58 \pm 1.16^{\mathrm{a}}$ & $138.01 \pm 1.16^{\mathrm{a}}$ & $132.97 \pm 1.64^{b}$ & 0.75 & 0.01 & 0.03 & 0.23 \\
\hline $\mathrm{K}(\mathrm{meq} / \mathrm{L})$ & $4.13 \pm 0.11$ & $4.26 \pm 0.11$ & $4.39 \pm 0.11$ & $3.94 \pm 0.15$ & 0.06 & 0.13 & 0.12 & 0.62 \\
\hline
\end{tabular}

Treatments: WNA=Water not available, $\mathrm{AW}=$ Adlibitum water, WAM= Water available after milk feeding, WBM= Water available before milk feeding

a,b Values within a row with different superscripts differ significantly at $\mathrm{P}<0.05$.

Table 5. Fecal score, temperature, and respiratory score of Holstein calves (Mean \pm SEM)

\begin{tabular}{lcccccc}
\hline \multirow{2}{*}{ Item } & \multicolumn{4}{c}{ Treatments } & \multirow{2}{*}{ SEM } & \multirow{2}{*}{ P } \\
\cline { 2 - 5 } & AW & WNA & WAM & WBM & & 0.78 \\
\hline Health score $^{1}$ & $1.53 \pm 0.53$ & $2.00 \pm 0.72$ & $2.15 \pm 0.51$ & $2.15 \pm 0.48$ & 0.23 & 0.78 \\
Nasal discharge & $0.30 \pm 0.17$ & $0.53 \pm 0.23$ & $0.61 \pm 0.17$ & $0.61 \pm 0.16$ & 0.07 & 0.43 \\
Respiratory score & $0.61 \pm 0.17$ & $0.76 \pm 0.23$ & $1.23 \pm 0.16$ & $1.15 \pm 0.16$ & 0.13 & 0.29 \\
Temperature $\left({ }^{\circ} \mathrm{C}\right)$ & 39.07 & 39.16 & 39.29 & 39.31 & 0.05 & 0.38 \\
Fecal score & $0.76 \pm 0.22$ & $1.15 \pm 0.29$ & $1.53 \pm 0.21$ & $1.15 \pm 0.20$ & 0.13 & 0.24 \\
\hline
\end{tabular}

Treatments: WNA=Water not available, $\mathrm{AW}=\mathrm{Ad}$ libitum water, WAM= Water available after milk feeding, WBM= Water available before milk feeding

${ }^{1}$ The day is getting sick until recovery

Table 6. Frame growth measurements and body condition scores for different water accessibility of Holstein calves with common starter and milk replacer (Mean \pm SEM)

\begin{tabular}{|c|c|c|c|c|c|c|c|c|}
\hline \multirow[t]{2}{*}{ Item (cm) } & \multicolumn{4}{|c|}{ Treatments } & \multirow{2}{*}{ SEM } & \multicolumn{3}{|c|}{$\mathbf{P}$} \\
\hline & $\mathbf{A W}$ & WNA & WAM & WBM & & Treat & Time & Treat $\times$ time \\
\hline Body length & $60.65 \pm 0.55$ & $60.69 \pm 0.55$ & $60.42 \pm 0.55$ & $60.34 \pm 0.55$ & 0.58 & 0.96 & 0.01 & 0.21 \\
\hline Withers height & $82.03 \pm 0.82$ & $83 \pm 0.85$ & $81.42 \pm 0.79$ & $82.38 \pm 0.81$ & 0.50 & 0.44 & 0.01 & 0.88 \\
\hline Heart girth & $82.92 \pm 0.80$ & $83.88 \pm 0.80$ & $81.65 \pm 0.80$ & $81.46 \pm 0.80$ & 0.69 & 0.11 & 0.01 & 0.76 \\
\hline Body barrel & $76.50 \pm 0.94$ & $77.19 \pm 0.94$ & $76.30 \pm 0.94$ & $75.15 \pm 0.94$ & 0.67 & 0.49 & 0.01 & 0.92 \\
\hline Hip height & $85.57 \pm 0.70$ & $86.57 \pm 0.70$ & $85.57 \pm 0.70$ & $85.92 \pm 0.70$ & 0.51 & 0.71 & 0.01 & 0.77 \\
\hline Hip width & $19.46 \pm 0.23$ & $19.30 \pm 0.23$ & $19.34 \pm 0.23$ & $19.09 \pm 0.23$ & 0.16 & 0.71 & 0.01 & 0.81 \\
\hline
\end{tabular}

Treatments: WNA=Water not available, $\mathrm{AW}=\mathrm{Ad}$ libitum water, $\mathrm{WAM}=$ Water available after milk feeding, WBM= Water available before milk feeding 
Table 7. Effects of water treatments on rumen fermentation parameters (Mean \pm SEM)

\begin{tabular}{lcccccc}
\hline \multirow{2}{*}{ Item } & \multicolumn{3}{c}{ Treatments } & \multirow{2}{*}{ SEM } & \multirow{2}{*}{ P } \\
\cline { 2 - 5 } & $\mathbf{A W}$ & WNA & WAM & WBM & & \\
\hline $\mathrm{NH}_{3}(\mathrm{mmol} / \mathrm{L})$ & $23.05 \pm 1.25$ & $23.42 \pm 1.35$ & $28.77 \pm 1.48$ & $31.27 \pm 1.65$ & 1.98 & 0.41 \\
Acetic acid $(\mathrm{mM})$ & $58.40 \pm 5.62^{\mathrm{a}}$ & $57.42 \pm 5.62^{\mathrm{a}}$ & $36.19 \pm 5.62^{\mathrm{b}}$ & $23.83 \pm 5.62^{\mathrm{b}}$ & 5.02 & 0.01 \\
Propionic acid (mM) & $28.39 \pm 4.42^{\mathrm{a}}$ & $22.00 \pm 4.42^{\mathrm{ab}}$ & $12.37 \pm 4.42^{\mathrm{b}}$ & $8.06 \pm 4.42^{\mathrm{b}}$ & 3.05 & 0.04 \\
Butyric acid (mM) & $7.04 \pm 2.11$ & $6.59 \pm 2.11$ & $8.35 \pm 2.11$ & $2.40 \pm 2.11$ & 1.12 & 0.29 \\
Isobutyrate $(\mathrm{mM})$ & $0.64 \pm 0.53$ & $2.01 \pm 0.53$ & $1.96 \pm 0.53$ & $0.92 \pm 0.53$ & 0.29 & 0.23 \\
Valerate $(\mathrm{mM})$ & $3.17 \pm 0.88$ & $2.93 \pm 0.88$ & $3.36 \pm 0.88$ & $1.17 \pm 0.88$ & 0.45 & 0.33 \\
Isovalerate $(\mathrm{mM})$ & $1.76 \pm 0.46$ & $1.91 \pm 0.46$ & $1.77 \pm 0.46$ & $0.88 \pm 0.46$ & 0.23 & 0.42 \\
\hline
\end{tabular}

Treatments: WNA=Water not available, $\mathrm{AW}=\mathrm{Ad}$ libitum Water, WAM= Water available after milk feeding, WBM= Water available before milk feeding, $\mathrm{mM}=$ milimolar

a,b Values within a row with different superscripts differ significantly at $\mathrm{P}<0.05$.

Table 8. Total times devoted to perform different behaviors during $8 \mathrm{~h}$ of observation in preweaning periods (Mean \pm SEM)

\begin{tabular}{|c|c|c|c|c|c|c|c|c|}
\hline \multirow[t]{2}{*}{ Item (h) } & \multicolumn{4}{|c|}{ Treatments } & \multirow{2}{*}{ SEM } & \multicolumn{3}{|c|}{$\mathbf{P}$} \\
\hline & AW & WNA & WAM & WBM & & Treat & Time & Treat $\times$ time \\
\hline Visit water bucket & $0.64 \pm 0.15^{\mathrm{a}}$ & $0.01 \pm 0.14$ & $0.40 \pm 0.15^{\mathrm{ab}}$ & $0.43 \pm 0.14^{\mathrm{a}}$ & 0.08 & 0.01 & 0.44 & 0.01 \\
\hline Visit starter bucket & $1.07 \pm 0.40$ & $1.61 \pm 0.35$ & $1.93 \pm 0.39$ & $1.25 \pm 0.38$ & 0.19 & 0.39 & 0.22 & 0.07 \\
\hline Rumination & $1.07 \pm 0.45$ & $1.11 \pm 0.40$ & $1.73 \pm 0.43$ & $1.00 \pm 0.42$ & 0.21 & 0.66 & 0.02 & 0.78 \\
\hline Standing & $1.21 \pm 0.41$ & $1.61 \pm 0.36$ & $1.06 \pm 0.40$ & $1.62 \pm 0.39$ & 0.18 & 0.66 & 0.58 & 0.95 \\
\hline Lying in bed & $1.85 \pm 0.97^{b}$ & $3.61 \pm 0.86^{\mathrm{ab}}$ & $2.80 \pm 0.94^{\mathrm{ab}}$ & $5.00 \pm 0.91^{\mathrm{a}}$ & 0.45 & 0.02 & 0.63 & 0.85 \\
\hline Object play & $1.92 \pm 0.49$ & $1.77 \pm 0.43$ & $1.66 \pm 0.47$ & $1.50 \pm 0.46$ & 0.22 & 0.92 & 0.54 & 0.62 \\
\hline Self grooming & $1.71 \pm 0.42$ & $1.05 \pm 0.37$ & $2.26 \pm 0.40$ & $1.50 \pm 0.39$ & 0.19 & 0.17 & 0.24 & 0.96 \\
\hline Nonnutritive sucking & $3.07 \pm 0.58$ & $2.88 \pm 0.51$ & $3.60 \pm 0.56$ & $3.18 \pm 0.54$ & 0.26 & 0.83 & 0.45 & 0.66 \\
\hline Other & $1.00 \pm 0.36$ & $1.11 \pm 0.32$ & $1.60 \pm 0.35$ & $1.00 \pm 0.34$ & 0.16 & 0.53 & 0.27 & 0.75 \\
\hline
\end{tabular}

Treatments: WNA=Water not available, $\mathrm{AW}=\mathrm{Ad}$ libitum water, WAM= Water available after milk feeding, WBM= Water available before milk feeding.

a,b Values within a row with different superscripts differ significantly at $\mathrm{P}<0.05$.

propionic acid of AW group significantly increased as compared with other treatments $(\mathrm{P}<0.05)$. As shown in Table 8, treatments did not affect behaviors parameters. But the number of visiting water bucket of AW and WBM were higher than other groups.

\section{Discussion and Conclusion}

De Passillé et al. (8) reported that that water intake of calves is low until weaning $(0.17 \mathrm{~kg} / \mathrm{d})$, whereas other calf studies measured considerable intakes of water (1 $\mathrm{kg} / \mathrm{d}$ ) (19). According to NRC (27), water intake will decrease with increasing cold until $4.4{ }^{\circ} \mathrm{C}$ and will remain constant for lower temperatures. In the different decade's age of calves' water intake, between groups had significantly changed, which may have been due to the accessibility of water in these groups during milk feeding calves. Kertz et al. (19) observed that daily water intakes decreased after 3 to $4 \mathrm{~d}$ of age compared with initial intakes. Increased DMI, and increased calf body size, which consequentially led to an increase in water requirements. The researchers indicated (3) demonstrated that total body water content of dairy calves decreased from 80 to $70 \%$ during the first $40 \mathrm{~d}$. According to Wenge et al. (34) restrictively-milk fed calves drank $1.1 \mathrm{~L}$ water per day within the first 3 weeks of life. The NRC (27) reported that water intake increases from $1 \mathrm{~kg} / \mathrm{d}$ at first week of age to $2.5 \mathrm{~kg} / \mathrm{d}$ at 4 weeks of age. Lower water drinking of calves in this study may be because of decreasing the air temperature.

The studies were revealed that starter intake affected by water accessibility as shown by Gonzalez (11) that water appears to have a relationship with starter intake as starter intake is a significant variable in predicting the water intake of a calf, especially after day 21 when starter intake and water intake are both increasing. Prior to 21 days, the relationship between water intake and starter intake is not significant but does trend to be related. These results corroborate the positive relationship normally observed between total DM intake and water intake (19). Conversely, when a greater volume of milk is offered (and indirectly, a greater amount of TS), there is a negative relationship between DM intake and voluntary water intake (21), because the liquid feed fills part of the need 
for water (2). Unlike water in milk, which is shunted directly to the abomasum, drinking water enters and becomes a part of the developing reticulorumen (hereafter called rumen) of pre-weaned calves (13). Therefore, voluntary water intake of pre-weaned calves $(0.75$ to 0.82 $\mathrm{kg} / \mathrm{d}$ ) partially represents a water requirement of the developing rumen. In this study higher water intake of AW and WBM groups maybe showed that water in calves after 10 days did not supply the requirements. Thus, calves had the potential to consume more water in this system. These results agree with De Passillé et al. (8) and Hepola et al. (15), who reported higher water intakes in calves fed limited quantities of milk. In contrast, higher starter intakes tend to increase the quantity of water consumed (19).

The contradictory alteration by different water accessibility on blood metabolites was shown by different studies, as Beiranvand et al. (5) reported that addition of water to the starter (up to $50 \% \mathrm{DM}$ ) had no significant effects on blood glucose concentration. Serum albumin concentrations partially reflect hepatic synthesis and its increasing could be related to compensation of decreasing serum osmotic pressure due to globulin levels decline. The level of total protein was below reference value at ages except at $24-48 \mathrm{~h}$ after birth. It was approximately similar to Knowles et al. (22) reports. Serum total protein levels were below previously reported reference range from birth up to day 84 of age (9) and from birth up to day 90 of age (36). Knowles et al. (22) revealed that albumin levels in calves were below the reference range of adults until after nine days of age.

It is well known that AST is a nonspecific marker of acute liver damage caused by high-grain diets and associated ruminal lactate production (25). The activities of AST were below the reference range. This is consistent with the Egli and Blum (9) study. Zanker et al. (36) reported a postnatal rise of AST activity had no association with the time of first colostrum intake, indicating that the rise of AST activity was the consequence of endogenous production and was independent of colostrum intake. Serum constituents and hematological profiles evaluated were within normal ranges reported by Kaneko (18).

Reece (30) reported that serum concentration of $\mathrm{Na}$, $\mathrm{K}$ and $\mathrm{Cl}$ in steers were 141.8, 4.6 and $105(\mathrm{mEq} / \mathrm{L})$, respectively. Roy et al. (31) indicated that Mean serumsodium values at birth were $139-140 \mathrm{mEq} / \mathrm{L}$. They revealed that most of the deaths occurred, when the sodium level was low and the potassium level normal. With the increasing incidence of scouring, a greater fall in mean serum-sodium values occurred. Mean serumpotassium levels at birth were 5.8-6.0 $\mathrm{mEq} / \mathrm{L}$. For calves that scoured on the 1 st day or not at all the mean serum potassium fell gradually to $5.8 \mathrm{mEq} / \mathrm{L}$ as the results of Roy et al. (31) study indicated clearly that, with an increased incidence of scouring the serum-sodium levels of calves decline with a concomitant but a slight rise in potassium values. NRC (27) showed that about eighteen times more water and eleven times more sodium and potassium were lost each day in the feces of scouring calves than in those of normal calves. They suggested that this loss was due to the increased osmotic pressure in the lumen of the gut owing to an increase in the number of smaller molecules, such as volatile fatty acids, resulting from bacterial activity. The higher osmotic pressure in the gut thus caused the infiltration of large amounts of water accompanied by electrolytes. It is well known that an increase in potassium concentration in the serum can occur with a cellular deficiency of potassium (30) and NRC (27) have emphasized that potassium should never be given to dehydrated patients because of the danger of an increase in potassium concentration in the serum and cardiac arrest. Wickramasinghe (35) reported that blood sodium concentrations of calves receiving drinking water from birth and calves that did not receive water during the first $17 \mathrm{~d}$ after birth were 134.4 and $136.1 \mathrm{mmol} \mathrm{/} \mathrm{L,}$ respectively. They revealed that this could be due to a greater intake of electrolyte solution given the greater severity of scours among calves did not receive water until days 17. Roy et al. (31) studied changes in serum sodium and potassium concentrations in 150 experimental calves, some of which became affected with diarrhea. They observed that diarrhea caused a decrease in serum sodium and an increase in serum potassium concentrations. Milk is a poor source of the major electrolytes lost in diarrhea $\left(\mathrm{Na}^{+}, \mathrm{Cl}^{-}, \mathrm{HCO}^{-}\right)(27)$. Reece (30) reported that in $46 \%$ of the plasma samples collected from diarrhoeic calves, the sodium concentrations were below normal. Since the diarrhoeic calves lost weight, and as part of this loss in body weight was presumably due to a reduction in body water (30), it would appear that these particular samples were from calves which were hypotonically dehydrated. However, as pointed out by Roy et al. (31), the plasma electrolyte concentration only shows the relative proportions of water to electrolytes in the plasma and in itself is not an indication of whether deficits or excesses of water and electrolytes are actually present in the body as a whole. Previous studies have confirmed (30) that in diarrheic calves there is characteristically a loss in body weight, negative sodium and potassium balance.

Overall, the calves in our study were healthy. This result agreed with Gottardo et al. (12) that reported calves receiving water showed a good health status throughout the fattening period, reducing the feed refusal days significantly. Water availability did not lead to the excretion of looser feces; therefore, no consequent detrimental effect on calves' body cleanliness was observed. Wickramasinghe et al. (35) reported that calves 
that 17 days delay of the offer first drinking water to newborn calves.

The excessive intake of drinking water might affect microbial fermentation in the rumen and thus rumen development. No study has examined the effect of water on rumen development of calves. Few studies focusing on the relationship between drinking water and rumen functions in mature cows provide some insight on the potential effects of drinking water in calves. For instance, Fraley et al. (10) found lower molar proportions of butyrate and propionate in the rumen, which were associated with lower liquid weight in the rumen and high fractional liquid passage rates in lactating cows with high water intake. Butyrate and propionate are often considered to be major drivers of morphological and metabolic developments of the rumen in calves (23). Therefore, the increased water intake of WBM calves could be hypothesized to inversely affect rumen development.

The number of drinking bouts recorded by Beiranvand et al. (5) resulted in mean values between 3 and 5 visits per animal per day and this was at a similar level compared to our own results. According to Gottardo et al. (12), the results of the two indicators illustrated that suckler cows showed climate-induced behavioral changes, whereas water intake was not influenced by increasing cold.

The results indicate that suckler calves with different water accessibility had different water intake. AW and WBM treatments drank more water than other groups $(\mathrm{P}<0.05)$. Water accessibility was also found to increase AST and $\mathrm{Na}$ concentration of serum but serum concentrations of protein and HDL and TAC levels were significantly higher in groups WNA and WAM than others $(\mathrm{P}<0.05)$. Different water accessibility of calves had no significant effects on respiratory and fecal score, growth parameters and behaviors. But acetic acid and propionic acid of AW groups significantly increased as compared with other treatments $(\mathrm{P}<0.05)$. Overall, in agreement with our hypotheses, giving water to young calves around milk meal had some beneficial effects but resulted in similar growth performance compared with calves that did not access to water. As a conclusion, it can be recommended that water accessibility around milk meal for suckling calves will be resulted in healthier calves.

\section{Acknowledgments}

Authors are grateful to the Isfahan University of Technology and the University of Mohaghegh Ardabili for their help.

\section{Financial Support}

This research received no grant from any funding agency/sector.

\section{Conflict of Interest}

The authors declare that they have no competing interests.

\section{References}

1. AOAC (2000): Method 973.18. Official methods of analysis. Association of Official Analytical Chemists, International, Gaithersburg, MD, USA.

2. Azevedo A, Machado FS, Campos MM, et al (2016): The effects of increasing amounts of milk replacer powder added to whole milk on feed intake and performance in dairy heifers. J Dairy Sci, 99, 8018-8027.

3. Bar-Peled U, Robinzon B, Maltz E, et al (1997): Increased weight gain and effects on production parameters of Holstein heifer calves that were allowed to suckle from birth to six weeks of age. J Dairy Sci, 80, 2523-2528.

4. Beede DK (2005): The most essential nutrient: Water. In: Proc. 7th Western Dairy Management Conf. Reno, NV, March 9-11, pp. 13-31.

5. Beiranvand H, Khani M, Omidian S, et al (2016): Does adding water to dry calf starter improve performance during summer? J Dairy Sci, 99, 1903-1911.

6. Chapman CE, Stone Wilkinson P, Murphy MR, et al (2017): Evaluating nuclear magnetic resonance spectroscopy for determining body composition in Holstein dairy calves using deuterium oxide dilution methods. J Dairy Sci, 100, 2807-2811.

7. Church DC (1991): Livestock feeds and feeding. 3rd ed. Prentice Hall, Englewood Cliffs, NJ.

8. De Passillé AM, Borderas TF, Rushen J (2011): Weaning age of calves fed a high milk allowance by automated feeders: Effects on feed, water, and energy intake, behavioral signs of hunger, and weight gains. J Dairy Sci, 94, 1401-1408.

9. Egli CP, Blum JW (1998): Clinical, hematological, metabolic and endocrine traits during the first three months of life of suckling simmentaler calves held in a cow-calf operation. J Vet Med A, 45, 99- 118.

10. Fraley SE, Hall MB, Nennich TD (2015): Effect of variable water intake as mediated by dietary potassium carbonate supplementation on rumen dynamics in lactating dairy cows. J Dairy Sci, 98, 3247-3256.

11. Gonzalez F (2009): Association among fluid, grain intake and weight gain in Holstein bull calve. M.sc. Thesis of Texas A \& M University.

12. Gottardo F, Mattiello S, Cozzi G, et al (2002): The provision of drinking water to veal calves for welfare purposes. J Anim Sci, 80, 2362-2372.

13. Govil K, Yadav DS, Patil AK, et al (2017): Feeding management for early rumen development in calves. J Entomol. Zool Stud, 5, 1132-1139.

14. Heinrichs AJ, Jones CM, VanRoekel LR, et al (2003): A system of dairy calf workforce management, training, and evaluation and health evaluation. J Dairy Sci, 86, 115-120.

15. Hepola HP, Hänninen LT, Raussi SM, et al (2008): Effects of providing water from a bucket or a nipple on the performance and behavior of calves fed ad libitum volumes of acidified milk replacer. J Dairy Sci, 91, 1486-1496. 
16. Iranian Council of Animal Care (1995): Guide to the care and use of experimental animals, vol. 1. Isfahan University of Technology, Isfahan, Iran.

17. Jasper J, Weary DM (2002): Effects of ad libitum milk intake on dairy calves. J Dairy Sci, 85, 3054-3058.

18. Kaneko JJ (1997): Serum proteins and the disproteinemias. In: Clinical biochemistry of domestic animals, Kaneko JJ, Harvey J.W and Bruss ML, (Ed.), pp. 117-138, Academic Press, San Diego, California,.

19. Kertz AF, Reutzel LF, Mahoney JH (1984): Ad libitum water intake by neonatal calves and its relationship to calf starter intake, weight gain, feces score and season. J Dairy Sci, 67, 2964-2969.

20. Khan MA, Bach A, Castells L, et al (2014): Effects of particle size and moisture levels in mixed rations on the feeding behaviour of dairy heifers. Animal, 8, 1722-1727.

21. Kiezebrink DJ, Edwards AM, Wright TC, et al (2015): Effect of enhanced whole-milk feeding in calves on subsequent first-lactation performance. J Dairy Sci, 98, 349-356.

22. Knowles TG, Edwards JE, Bazeley KJ, et al (2000): Changes in the blood biochemical and haematological profile of neonatal calves with age. Vet Rec, 147, 593-598.

23. Lane MA, Baldwin VIRL, Jesse BW (2000): Sheep rumen metabolic development in response to different dietary treatments. J Anim Sci, 78, 1990-1996.

24. Lesmeister KE, Heinrichs AJ (2004): Effects of corn processing on growth characteristics, rumen development and rumen parameters in neonatal dairy calves. J Dairy Sci, 87, 3439-3450.

25. Mori A, Urabe S, Asada M, et al (2007): Comparison of plasma metabolite concentrations and enzyme activities in beef cattle raised by different feeding systems in Korea, Japan and New Zealand. J Vet Med A Physiol Pathol Clin Med, 54, 342-345.

26. Murphy MR (1992): Water metabolism of dairy cattle. J Dairy Sci, 75, 326-333.

27. NRC (2001): Nutrient requirements of dairy cattle. 7th. rev. ed. National Acad. Sci. Washington, DC.
28. Pempek JA, Eastridge ML, Swartzwelder SS, et al (2016): Housing system may affect behavior and growth performance of Jersey heifer calves. J Dairy Sci, 99, 569578.

29. Quigley J (2000): Predicting water intake in young calves. Available at: http://www.calfnotes.com. (Accessed Nov 11, 2000).

30. Reece WO (1984): Acid-base balance and selected hematologic, electrolytic, and blood chemical variables in calves nursing cows: one week through fifteen weeks. Am J Vet Res 45, 666-669.

31. Roy RN, Chance GW, Radde IC, et al (1976): Late hyponatraemia in very low birth weight infants less than 1.3 kg. Pediatr Res, 10, 526-531.

32. SAS Institute, 'SAS/STATuser's guide: Statistics. Version 9.1, (SAS Institute Inc. Cary, NC), 2001.

33. TierSchNutzt.V (Tierschutz-Nutztierhaltungsverordnung) (2006): Regulation on the protection of livestock and other animals kept for the production of animal products in their attitude. 11. Monitoring, caring and feeding of calves. Bundesjustizministerium (Federal Ministry of Justice), Berlin, Germany.

34. Wenge J, Steinhöfel I, Heinrich C, et al (2014): Water and concentrate intake, weight gain and duration of diarrhea in young suckling calves on different diets. Livest Sci, 159, 133-140.

35. Wickramasinghe HKJP, Kramer AJ, Appuhamy JADRN (2019): Drinking water intake of newborn dairy calves and its effects on feed intake, growth performance, health status, and nutrient digestibility. J Dairy Sci, 102, 377-387.

36. Zanker I A, Hammon HM, Blum JW (2001): Activities of $\gamma$-Glutamyltransferase, alkaline phosphatase and aspartateaminotransferase in colostrum, milk and blood plasma of calves fed first colostrum at 0-2, 6-7, 12-13 and 24-25 h after Birth. J Vet Med A Physiol Pathol Clin Med, 48, 179185 . 